\title{
Immunohistochemical study of gonadotropin-releasing hormone and somatolactin during induced spawning of Liza ramada
}

\author{
Original \\ Mostafa A. Mousa', Noha A. Khalil', Amal M. Hashem ${ }^{2}$ and Mohamed F. Kora ${ }^{1}$ \\ Article \\ ${ }^{1}$ Fish Reproduction Laboratory, National Institute of Oceanography and Fisheries, Alexandria, \\ ${ }^{2}$ Department of Zoology, Faculty of Science, Zagazig University, Zagazig, Egypt
}

\begin{abstract}
Introduction: Gonadotropin releasing hormone $(\mathrm{GnRH})$ is a crucial regulator of gonadal development and reproduction in fish. In addition, it is a possible secretagogue of somatolactin (SL) in teleosts. Little is known about the possible association of GnRH and SL during reproduction of Liza ramada.

Aim of the work: The present study was designed to investigate the GnRH and SL immunoreactivities during inducing the final stages of maturation, ovulation and spawning of Liza ramada; to assess the possible actions of these hormones on sexual maturation and spawning of teleosts.

Materials and Methods: Histological and immunohistochemical techniques were generally performed to describe the immunoreactivity of both GnRH and SL during ovarian maturation and spawning of Liza ramada.

Results: The mammalian GnRH (mGnRH) cell bodies were observed in the medulla oblongata. However, SL-immunoreactive (-IR) cells were detected in the pars intermedia (PI) of the pituitary gland. The GnRH-IR nerve terminals are in close contact with SL-IR pituitary cells. Importantly, the activity of both mGnRH-IR neurons and SL-IR pituitary cells were increased as reflected with the increased cell number and size during sexual maturation and spawning. The activity of these cells was more pronounced as indicated by the increased cells number and size with more immunoreactivity in pre-spawning female. During final maturation and spawning, mGnRH-IR neurons and SL cells showed an increase in the secretory activity as reflected by their small sizes, vacuolated appearance and weak immunoreactivity.

Conclusions: Taken together, these findings suggest that the close contact of mGnRH-IR terminals with SL-IR cells in the pituitary, together with the concomitant changes of GnRH and SL immunoreactivity in response to progress in the reproductive events suggest that GnRH may regulate SL release and the regulation of reproductive activity in L. ramada.
\end{abstract}

Key Words: Gonadotropin-releasing hormone, Immunocytochemistry, liza ramada, maturation, ovulation, somatolactin, spawning.

Revised: 24 March 2017, Accepted: 17 August 2017

Corresponding Author: Mostafa A. Mousa, Tel.: 01001082930, E-mail: mostafa_mousa2002@yahoo.com, National Institute of Oceanography and Fisheries.

ISSN: 1110-0559, September Vol. 40, No. 3

\section{INTRODUCTION}

Spawning induction of cultured fish by hormonal treatments is one of the ways to produce fry for stocking ponds. Similar to females of many commercially important fishes, mullet do not undergo final oocyte maturation (FOM), ovulation or spawning in captivity ${ }^{[1-3]}$. Consistently, the ova will not advance to final maturation and ovulation without exogenous hormone stimulation, but will undergo atresia and degenerate. Therefore, it is necessary to induce maturation and ovulation with exogenous hormone stimulation. Indeed, the induced ovulation technique using acute injections of hormones including $\mathrm{GnRH}$ is an important step in the development of the mullet ${ }^{[3,4]}$ or Chondrostoma nasus, Cyprinidae ${ }^{[5]}$ culture.

$\mathrm{GnRH}$ is a decapeptide neuroendocrine hormone that is considered to play important roles in the regulation of teleosts reproduction, mainly by stimulation of gonadotropin release from the pituitary gland ${ }^{[6-9]}$. Teleost fishes lack a functional-hypophyseal portal system, but GnRH nerve fibers terminate in the vicinity of the pituitary gonadotrophs ${ }^{[10,11]}$. Recently, a growing body of data suggests the involvement of $\mathrm{GnRH}$ in regulating the secretion of various pituitary hormones including SLexpressing cells were observed in L. niloticus ${ }^{[11,12]}$, genus Oncorhynchus ${ }^{[13-15]}$, the steelhead trout and O. mykiss ${ }^{[16]}$. SL is a pituitary hormone closely related to GH and is only found in fish. SL is involved in the regulation of different physiological processes, including reproduction ${ }^{[17-22]}$, acid-base and calcium regulation ${ }^{[13,23,24]}$, phosphate and fat metabolism ${ }^{[25,26]}$, and background adaptation ${ }^{[27-29]}$. SL has also been linked to fish reproduction. Indeed, SL cells in the PI are activated during the reproductive phase in the genus Oncorhynchus ${ }^{[19,30]}$ and Odontesthes bionariensis ${ }^{[31]}$. In addition, seasonal variations in the 
number, size, and intensity of the immunoreaction of SL cells were observed concomitant with the development of the gonads and spawning in O. niloticus and Mugil cephalus $^{[17,18]}$. Moreover, the close association of GnRHIR fibers with various pituitary hormones secreting cells including SL-expressing cells; suggests that SL-producing cells are regulated by $\mathrm{GnRH}^{[11,32]}$. Both hormones regulate the reproductive activity in teleosts, however, little is known about the possible association of GnRH and SL during sexual maturation and spawning of thin-lipped grey mullet. Therefore, we aimed to investigate $\mathrm{GnRH}$ and SL immunoreactivities during stimulating oocyte final maturation, ovulation and spawning to assess the possible actions of these hormones on sexual maturation and spawning of thin-lipped grey mullet; L. ramada. Our results may provide information that could be critical for the development of reliable methods of spawning induction in this and other commercially important species.

\section{PATIENTS AND METHODS}

This study was carried out at El-Matareyya Research Station and Zoology Department, Faculty of ScienceZagazig University during the spawning season in the period from $1^{\text {st }}$ November, 2014 and $31^{\text {st }}$. January 2015.

\section{Broodstock collection}

Mature breeders of thin-lipped grey mullet, at least two-years-old, with total weights ranged from 300 to 600 $\mathrm{g}$ with total lengths $30-40 \mathrm{~cm}$, were collected alive, by draining water completely, during the spawning season (November to January) from freshwater culture ponds (at El-Serw Fish Research Station). Sexes were identified based on spermiation for males and slightly distended abdominal condition for females.

\section{Seawater acclimation and induction of spawning}

The present experiments were carried out, during the natural spawning season of thin-lipped grey mullet. The fish were anesthetized in a solution $(40 \mathrm{mg} / \mathrm{l})$ of clove oil (Sigma) before handling ${ }^{[33]}$. Mature females of thin-lipped grey mullet were selected on the basis of the presence of a soft, swollen abdomen and protruding genital papillae. The maturity and the oocyte diameters of the females were staged by obtaining in vivo biopsy of the ovary using a polyethylene cannula ${ }^{[34]}$. The females that were used possessed oocytes whose diameters were greater than 600 $\mu \mathrm{m}$. Ripe males in which milt could be easily extruded, by gentle pressure on their bellies, were used. Selected breeders were acclimated in 2000-litre circular fiberglass tanks (10 fish/tank). In brief, fish were transferred to water with $10 \%$ salinity (for $12 \mathrm{~h}$ ) which gradually increased to $35 \%$ (for another $12 \mathrm{~h}$ ).

Acclimated breeders were transferred to 500-litre fiberglass tanks equipped with constant running ozonated seawater $(35 \%)$ and aeration (Female +2 males/tank) for induction of spawning with human chorionic gonadotropin (HCG) "pregnyl" (Nile Co. for Pharmaceuticals, Cairo,
ARE) alone or in combination with LHRH-a. The protocol of hormonal injection was previously described ${ }^{[3]}$. Water temperature and salinity were $19^{\circ} \mathrm{C}$ and $35 \%$, respectively.

\section{Tissue processing and histology}

Ten fish from each stage during induction of spawning; pre-spawning, mature and post-spawning females, were taken for histological and immunohistochemical investigations. The fishes were anesthetized in a solution (40 $\mathrm{mg} / \mathrm{L}$ ) of clove oil (Sigma) before handling ${ }^{[33]}$. The gonadal biopsies were examined immediately after anesthesia. Oocyte diameter and morphology were examined microscopically. The diameter of at least 25 of the largest oocytes was recorded from each fish, and the position of the germinal vesicle $(\mathrm{GV})$ was determined after clearing the cytoplasm for 10 min with a 1:1:1 v/v methanol: ethanol: acetic acid solution ${ }^{[35]}$. The anesthetized fish perfused via the ascending aorta with $20 \mathrm{ml}$ of normal saline, followed by $50 \mathrm{ml}$ of Bouin's fluid at $4^{\circ} \mathrm{C}$. Immediately after the dissection, the pituitary gland, attached to the brain, was post-fixed in Bouin's fluid for $24 \mathrm{~h}$ at $4^{\circ} \mathrm{C}$. The gonads were removed and post fixed in Bouin's fluid for $24 \mathrm{~h}$ at $4^{\circ} \mathrm{C}$. Thereafter, the fixed gonads, brain and pituitaries were dehydrated through graded ethanol solution, cleared and embedded in paraplast (M.P.: $56-58^{\circ} \mathrm{C}$ ). Consecutive transverse sections were made at $4 \mu \mathrm{m}$ thickness. Sections of gonads were stained with Harris's alum hematoxylin ${ }^{[36]}$ and aqueous solution of eosin as a counter stain.

\section{Immunohistochemical procedures}

Antibodies: Rabbit antisera directed against GnRH antisera: mGnRH (83LRF) (G. Tramu, Avenue des Facultés, Talence, France), salmon GnRH (Lot No. 1668) (J.A. King, University of Cap Town, South Africa), cGnRHII (Rüdiger W. Schulz, University of Utrecht, Faculty of Biology, The Netherlands), cGnRHII (aCII6) (Koichi Okuzawa, National Research Institute of Aquaculture, Mie, Japan), Lamprey I GnRH (Lot 21134-), and Lamprey III GnRH (Lot 3952) (Stacia Sower, University of New Hampshire, USA). In addition, antiserum directed against chum salmon somatolactin (Lot No. 8906) was obtained from Dr. H. Kawauchi (School of Fisheries Science, Kitasato University, Iwate, Japan).

\section{Immunohistochemistry}

Immunocytochemical staining for the sections of the pituitary gland and brain was generally performed with a vectastain $\mathrm{ABC}$ (avidin-biotin peroxidase complex) Kit (Vector Laboratories) as described previously [17]. In brief, sections were deparaffinized in xylene, rehydrated through graded ethanol, washed in phosphate-buffered saline (PBS; $\mathrm{pH}$ 7.4) for two times 10 min each. All incubations were done at $4{ }^{\circ} \mathrm{C}$ and PBS was used for washing after each step. Sections were incubated with the antisera to the various GnRHs overnight at $4^{\circ} \mathrm{C}(1: 1000$ for each of 1GnRH-I, lGnRH-III, sGnRH (1668), cGnRH-II, and $\mathrm{mGnRH}$ (83LRF). Thereafter, the sections were incubated with 
the biotinylated secondary antibody (Vector Laboratories) for $1 \mathrm{~h}$ and with avidin-biotin-conjugated peroxidase for $45 \mathrm{~min}$. Finally, the sections were washed and stained with 3', 3'--diaminobenzidine tetrahydrochloride (DAB) (Sigma) including $0.01 \% \mathrm{H} 2 \mathrm{O} 2$ in $0.05 \mathrm{M}$ Tris-buffered saline ( $\mathrm{pH} 7.6$ ) for $3-5 \mathrm{~min}$. After the enzyme reaction, the sections were washed in tap water, dehydrated in ethyl alcohol, cleared in xylene, and mounted in DPX (Din-butylPhthalate in Xylene; Fluka Chemie AG, Buchs, Switzerland).

\section{Immunohistochemical double staining}

To study co-localization of $\mathrm{mGnRH}$ and SL using double peroxidase immunohistochemistry with a vectastain ABC (Avidin-biotin peroxidase complex) Kit (Vector Laboratories) as described previously ${ }^{[11]}$. The sections of the pituitary gland and brain were deparaffinized in xylene, rehydrated through graded ethanol and washed in phosphate-buffered saline (PBS). Then, the sections were treated with $0.6 \% \mathrm{H} 2 \mathrm{O} 2$ for $30 \mathrm{~min}$ to inactivate peroxidase in $\mathrm{ABC}$ and washed in several changes of PBS. Sections stained for $\mathrm{mGnRH}$ were then incubated with a second primary antibody against SL (Lot No. 8906, 1:1 000 dilution) (H. Kawauchi, School of Fisheries Science, Kita-sato University, Iwate, Japan). All incubations were done overnight at $4^{\circ} \mathrm{C}$. Slides were then washed in PBS, exposed to the biotinylated secondary antibody (Vector Laboratories) for $1 \mathrm{~h}$. and with avidin $\neg$ biotinconjugated peroxidase for $45 \mathrm{~min}$. Finally, the sections were washed and stained with 3', 3'--diaminobenzidine tetrahydrochloride (DAB) (Sigma) including $0.01 \%$ $\mathrm{H} 2 \mathrm{O} 2$ in $0.05 \mathrm{M}$ Tris-buffered saline ( $\mathrm{pH}$ 7.6) for $35-\mathrm{min}$. Sections stained with anti-GnRH antibody were washed in several changes of PBS. Sections were then incubated, overnight at $4^{\circ} \mathrm{C}$, with a second primary antibody against chum salmon somatolactin, washed in PBS, exposed to the biotinylated secondary antibody (Vector Laboratories) for $1 \mathrm{~h}$. and with avidin-biotin-conjugated peroxidase for $45 \mathrm{~min}$. Finally, the sections were washed and stained with 3', 3'--diaminobenzidine tetrahydrochloride (DAB) (Sigma) including $0.01 \% \mathrm{H} 2 \mathrm{O} 2$ in $0.05 \mathrm{M}$ Tris-buffered saline ( $\mathrm{pH}$ 7.6) for 35- min. During staining with DAB, the nickel solution was used to differentiate between the double immunostaining. The chromogen DAB used for the first primary antiserum appeared black, whereas the one used for the second primary antiserum appeared brown. After the enzyme reaction, the sections were washed in tap water, dehydrated in alcohol, cleared in xylene and mounted in DPX.

\section{Specificity controls}

To demonstrate specificity of staining, the following controls were included as mentioned in details elsewhere ${ }^{[11]}$ : (1) Preabsorption of antibody against $\mathrm{mGnRH}$ and SL with a synthetic peptide for $\mathrm{mGnRH}$ (Sigma) and SL (H. Kawauchi) for $24 \mathrm{~h}$ at $4{ }^{\circ} \mathrm{C}$ (2) omission of either the first or second primary antibody and either the first or second and secondary antibody.

\section{Cell size measurements}

Quantification of SL $\neg$ immunoreactive cells in the PI was calculated from four sections of each individual animal ( $\mathrm{n}=8$ in each maturity stage). The soma sizes of neurons immunoreactive to $\mathrm{mGnRH}$ in the NLTP as well as SL-ir pituitary cells were measured using computeraided analysis (the Image-Pro Analysis package, Media Cybernetics) of digital images viewed via microscope (Axioskope, Zeiss, Oberkochen, Germany). A3CCD color video camera, (Sony) was used for a minimum of $50 \mathrm{mGnRH}$-ir neurons from each brain area under investigation (NL TP) per animal as well as 50 SL-ir cells from PI, the cross-sectional area was measured for neurons with the nucleus in the plane of section.

\section{Statistical analysis}

Differences between treatments were tested by one-way ANOVA using the treatment as factor of variance. StudentNewman-Keuls test or Holm-Sidak method were used to identify significant differences between all groups or compared to control, respectively. Statistical significance was accepted at $\mathrm{P}<0.05$.

\section{RESULTS}

\section{Induced spawning}

The breeders were successfully acclimated to seawater $(35 \%)$ prior to hormonal injection. High rate $(100 \%)$ of ovulation and spawning was achieved in L. ramada females utilizing pregnyl (HCG) as priming and resolving injections. All the injected females were spawned at a time of 44 to $52 \mathrm{~h}$ after hormonal injection.

\section{Histological characters of post-vitellogenic and mature oocytes}

All females prior to hormonal injection contained vitellogenic oocytes varying in diameter from 600 to 650 $\mu \mathrm{m}$. Vitellogenic (tertiary yolk) oocytes had a centrally located germinal vesicle $(\mathrm{GV})$, and their cytoplasm was filled mostly with yolk globules and lesser number of unstained lipid droplets scattered throughout the cytoplasm (Fig. 1a).

\section{Final oocyte maturation and spawning of hormonal-injected fish}

Based on the morphological and histological changes; oocyte maturation was identified into two stages. Early maturation stage, which included lipid-droplet coalescence and germinal vesicle migration, and the late maturation stage included germinal vesicle breakdown (GVBD) and yolk-globule coalescence (Figs. 1a, 1b, 2a2c).

The first morphological change after hormonal induction was the fusion and coalescence of the lipid droplets. At this stage the GV was located between the 
center and the periphery of the oocyte, and was always in association with the largest lipid mass (Figs. 1b and $2 b)$. The germinal vesicle was still intact at the end of the early maturation stage and was localized adjacent to the lipid mass in the peripheral cytoplasm (Figs. 1b and 2b). Development to this stage (early maturation) from the time of hormonal treatment of post-vitellogenic oocytes required 24 to $36 \mathrm{hs}$.

Once lipid-droplet coalescence was completed, germinal vesicle breakdown took place soon afterwards. By this time, the clearing process began in which the oocytes appear progressively more translucent (Fig. $3 c)$. Late oocyte maturation lasted after $2430-$ hs. The ovulated eggs were free, pelagic and transparent and vary in diameter between 0.9 and $1.0 \mathrm{~mm}$ (Fig. 3c).

The post-spawning ovaries were characterized by a great number of relatively deformed oocytes and remains of empty follicles (Figs. 1c and 1d). In addition, the post-spawning ovaries of L. ramada contained primary oocytes (Figs. 1c and 1d).

\section{Immunohistochemistry of GnRH during induction}

\section{of spawning in female L. ramada}

Different GnRH antisera were used in the present study. Only mGnRH was localized in neurons located in the medulla oblongata in the brain of L. ramada females (Figs. 3a-3f). During the pre-spawning stage of the ovaries, the synthetic activity of $\mathrm{mGnRH}$ neurons was high as reflected with strong immunoreactivity and increased sizes and numbers (Figs. $3 a$ and $3 b$ ). At this stage mGnRH-IR neurons were impregnated with coarse immunoreactive granules (Figs. 3a and 3b). By approach the final maturation of the ovary, the immunostaining intensities and size of mGnRH neurons were markedly reduced compared to that of pre-spawning female (Figs. $3 a-3 d)$. Most of mGnRH-IR neurons became elongated in shape and contained coarse immunoreactive granules (Figs. 3c and 3d). In the post-spawned fish with spent ovaries, most of mGnRH neurons appeared to empty their secretory contents as indicated by their small size and vacuolated cytoplasm (Figs. 3e and 3f).

\section{Double immunostaining of $m G n R H$ and $S L$ in the}

\section{pituitary gland during induction of spawning in}

\section{female L. ramada}

mGnRH-IR fibers appear in close contact with SL-IR cells in the PI of the pituitary gland of L. ramada females (Figs. 4a-4c). mGnRH-IR fibers exhibited high intensities and little decrease of mGnRH immunoreactivity during final ovarian maturation compared to that of pre- spawning female (Fig. 4a and 4b). After spawning, the density and immunoreactivity of mGnRH-IR fibers were decreased (Fig. 4c).

In the pre-spawning females, SL-IR cells exhibited strong immunoreactivity, increased sizes and numbers (Fig. 4a). During the final maturation of the ovary, SLIR cells appeared with reduced immunoreactivity in comparison to that of pre-spawning female (Figs. 4a and 4b). After spawning, SL-IR cells appeared to empty their secretory contents as indicated by their immunoreactivity and vacuolated cytoplasm (Fig. 4c).

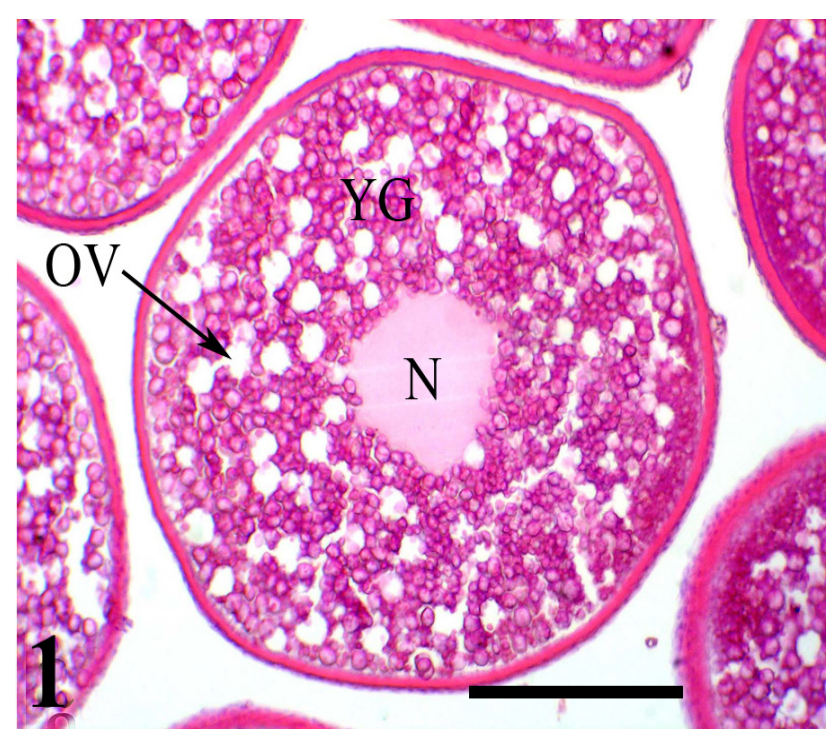

Fig. 1: Transverse section of ovary of post-vitellogenic L. ramada female before injection of hormones, stained with Harris's hematoxylin and eosin: showing tertiary yolk oocyte which has central-located nucleus $(\mathrm{N})$, ooplasm impregnated with yolk globules (YG) and lesser number of oil vesicles $(\mathrm{OV})$ distributed in the ooplasm. Scale bar $=250 \mu \mathrm{m}$.

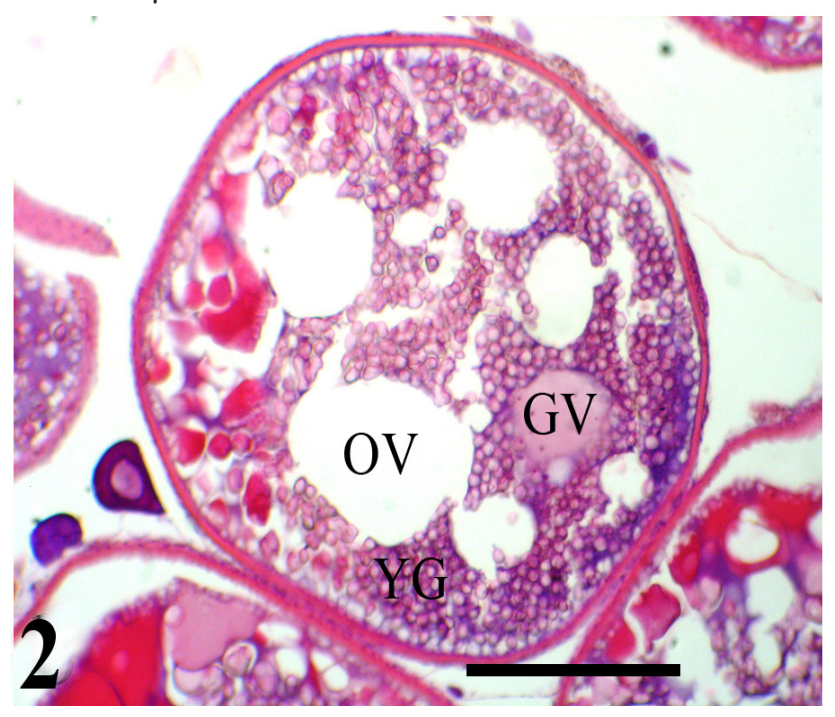

Fig. 2: Transverse section of ovary of injected L. ramada female, stained with Harris's hematoxylin and eosin: undergoing maturation, showing the oil vesicles (OV) coalescence, packed yolk globules (YG) and migration of germinal vesicle (GV) to the peripheral cytoplasm. Scale bar $=250 \mu \mathrm{m}$. 


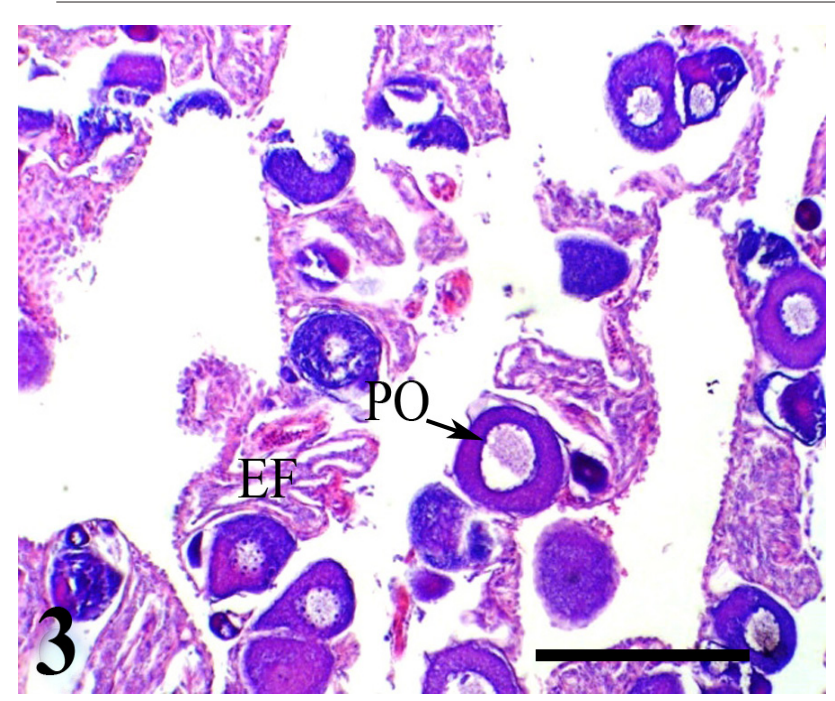

Fig. 3: Transverse sections of spent ovary of hormonalinduced spawning L. ramada, stained with Harris's hematoxylin and eosin: showing empty follicles (EF) and primary oocyte $(\mathrm{PO})$. Scale bar $=250 \mu \mathrm{m}$.

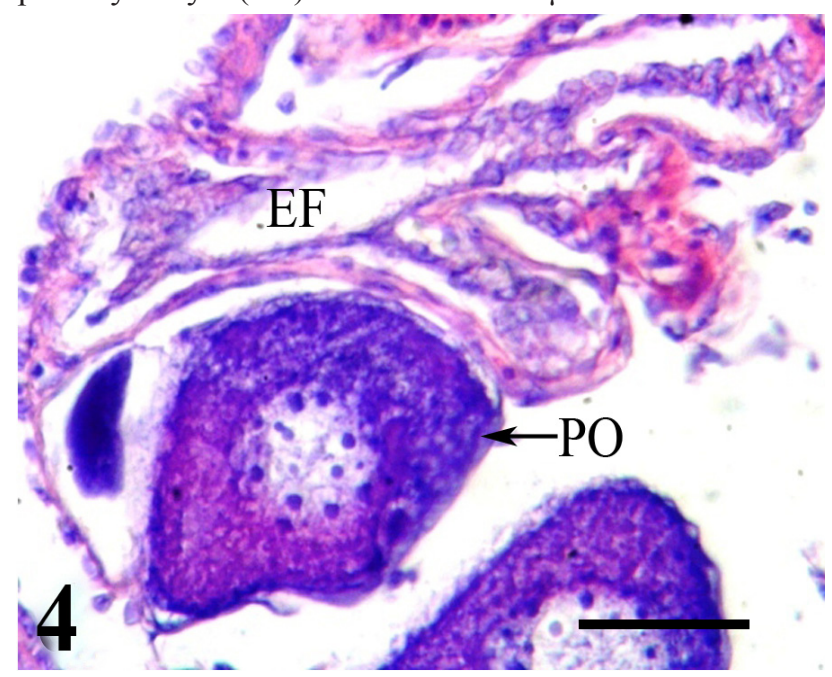

Fig. 4: A magnified portion of figure (3) showing empty follicles (EF) and primary oocyte (PO). Scale bar $=50 \mu \mathrm{m}$.

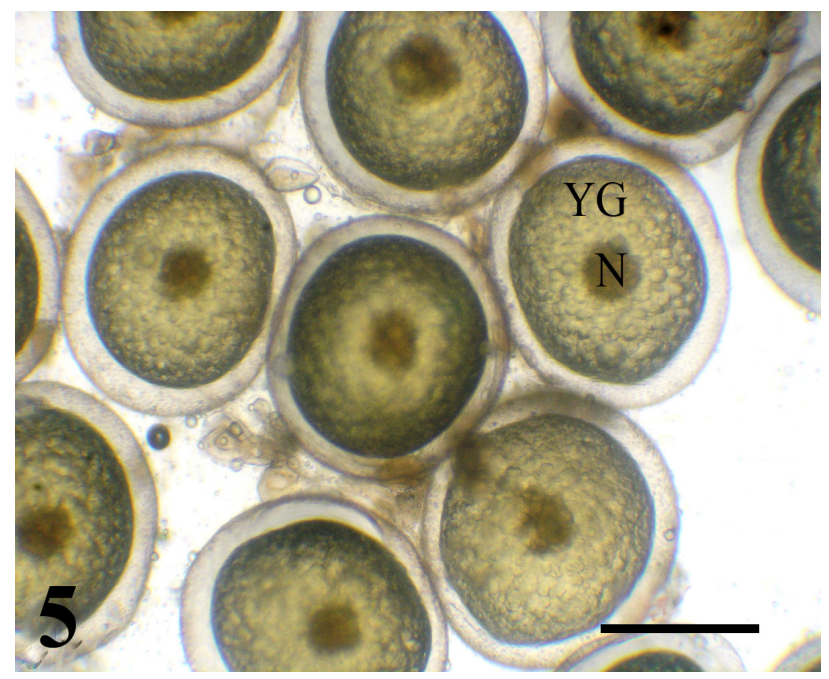

Fig. 5: Macroscopic view of pre-spawning tertiary yolk oocytes which have central-located nucleus $(\mathrm{N})$, ooplasm impregnated with yolk globules (YG). Scale bars $=400$ $\mu \mathrm{m}$.

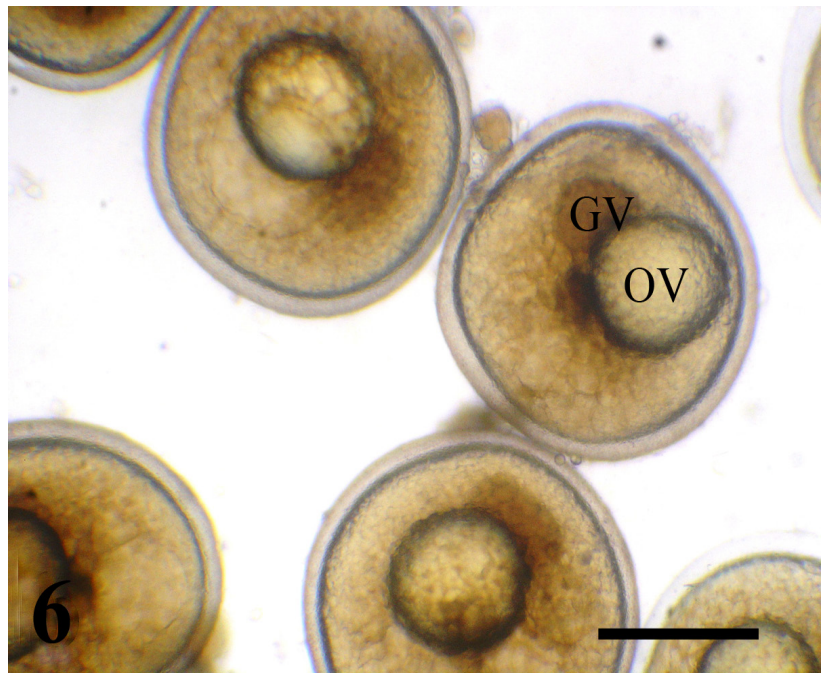

Fig. 6: Macroscopic view of mature oocytes, of injected L. ramada female, showing the oil vesicles (OV) coalescence and migration of germinal vesicle $(\mathrm{GV})$ to the peripheral cytoplasm. Scale bars $=400 \mu \mathrm{m}$.

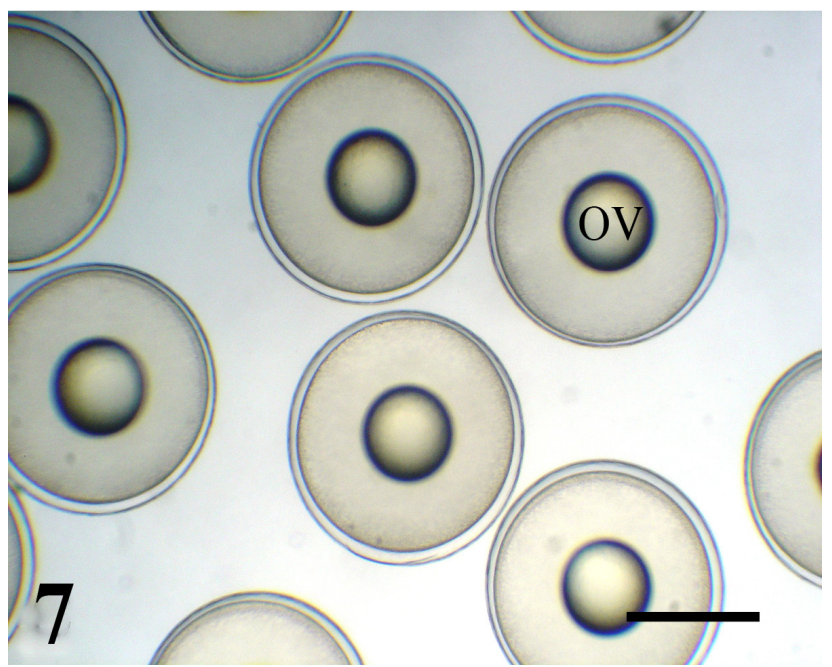

Fig. 7: Macroscopic view of ovulated eggs with one oil vesicle $(\mathrm{OV})$. Scale bars $=500 \mu \mathrm{m}$.

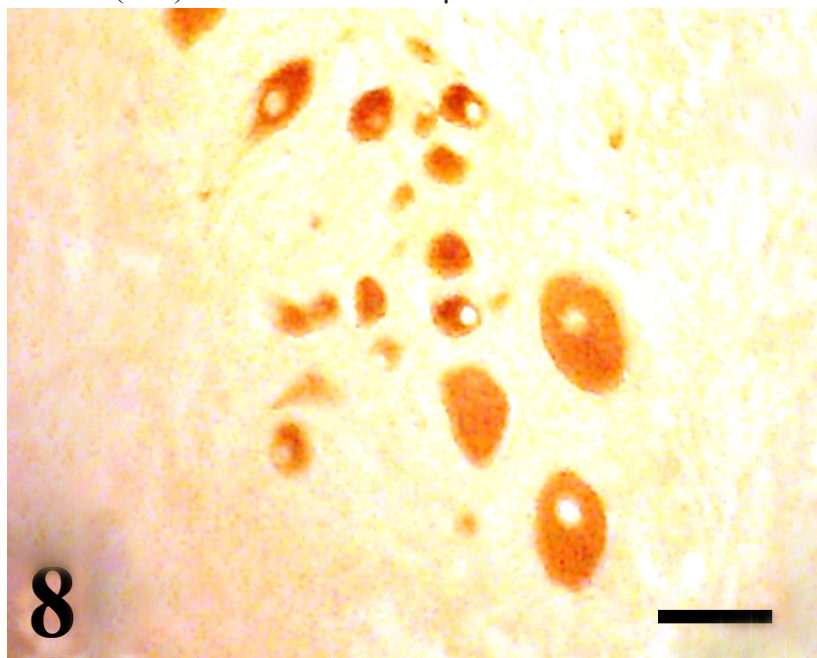

Fig. 8: Sagital sections through the medulla oblongata in the brain of L. ramada female, showing mGnRH-IR cell bodies of pre-spawning female have different shapes and sizes, with strong immunoreaction. Scale bars $=20 \mu \mathrm{m}$. 


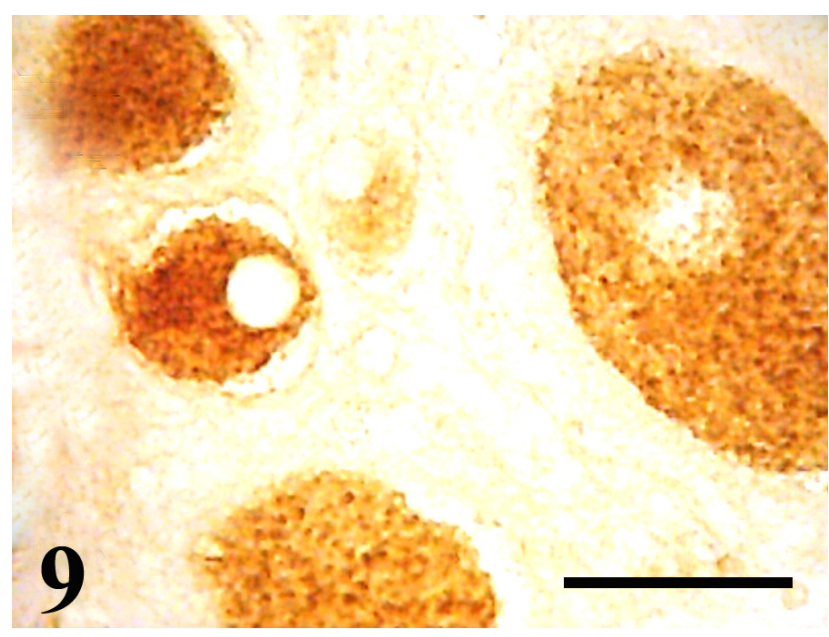

Fig. 9: Sagital sections through the medulla oblongata in the brain of pre-spawning L. ramada female, showing mGnRH-IR cells impregnated with large (coarse) immunoreactive granules. Scale bars $=10 \mu \mathrm{m}$.

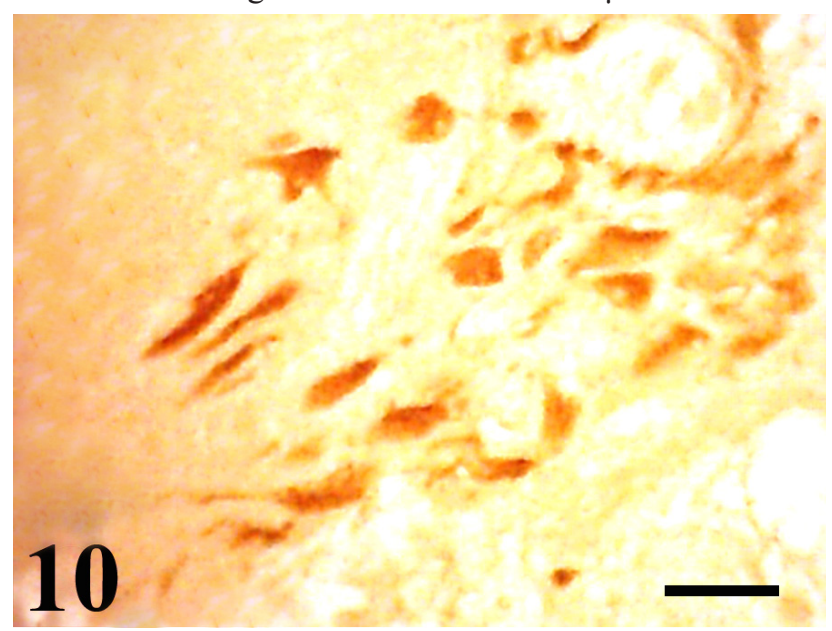

Fig. 10: Sagital sections through the medulla oblongata in the brain of L. ramada female, during ovarian maturation and spawning, showing mGnRH-IR cell bodies of mature injected female, having small sizes, with moderate immunoreaction. Scale bars $=20 \mu \mathrm{m}$.

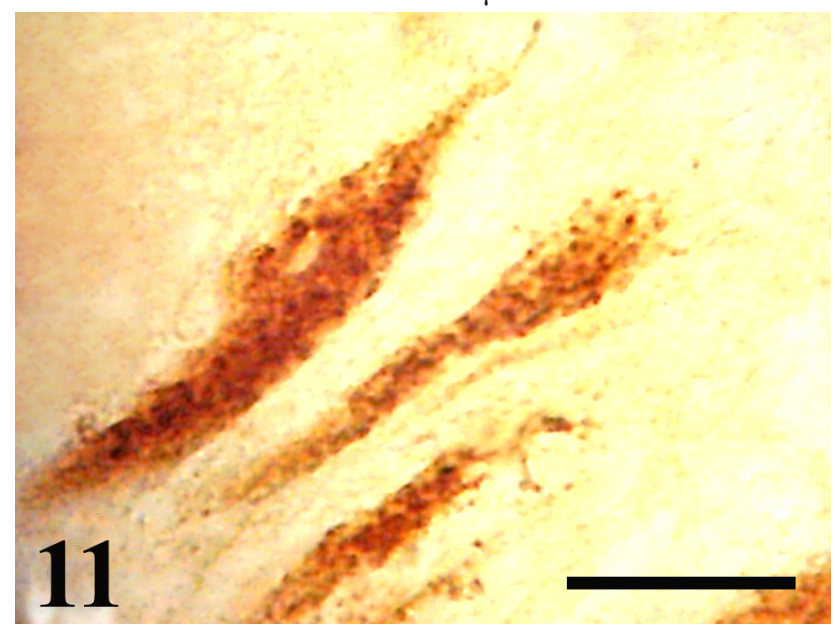

Fig. 11: Sagital sections through the medulla oblongata in the brain of mature injected L. ramada female showing mGnRH-IR cells decreased in size and with large (coarse) immunoreactive granules. Scale bars $=10 \mu \mathrm{m}$.

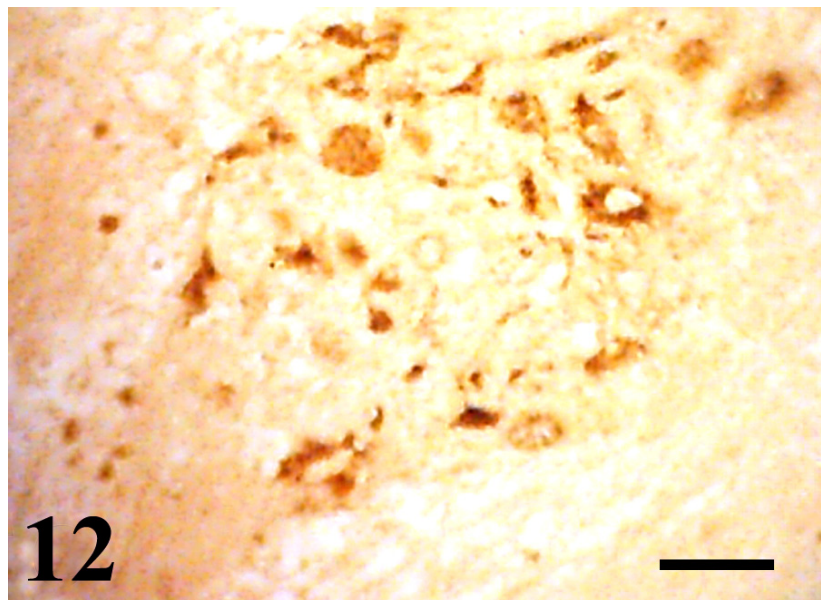

Fig. 12: Sagital sections through the medulla oblongata in the brain of $\mathrm{L}$. ramada female, during ovarian maturation and spawning, showing mGnRH-IR cell bodies of postspawning female, have small sizes and weak immunoreactivity. Scale bars $=20 \mu \mathrm{m}$.

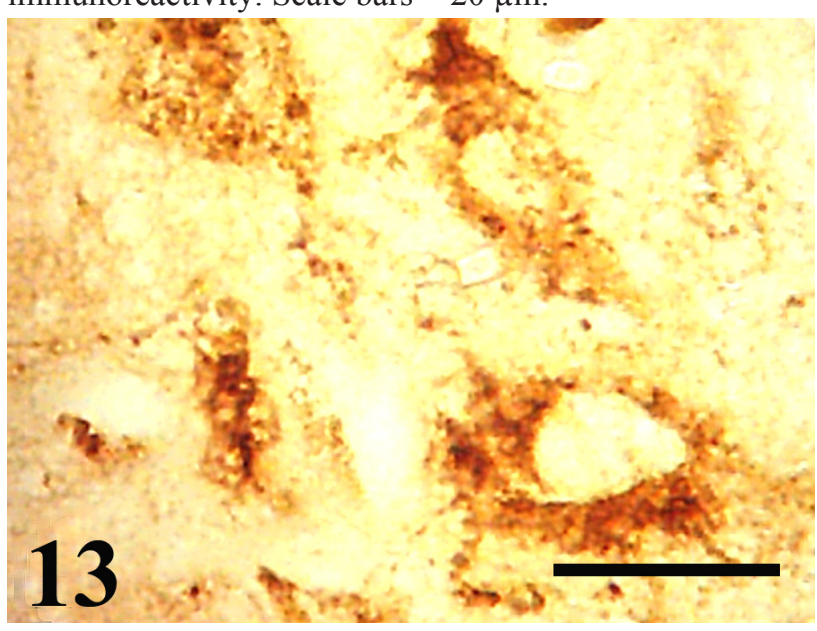

Fig. 13: Sagital sections through the medulla oblongata in the brain of L. ramada postspawning female, showing mGnRH-IR cells have different sizes and with few immunoreactive granules. Scale bars $=10 \mu \mathrm{m}$.

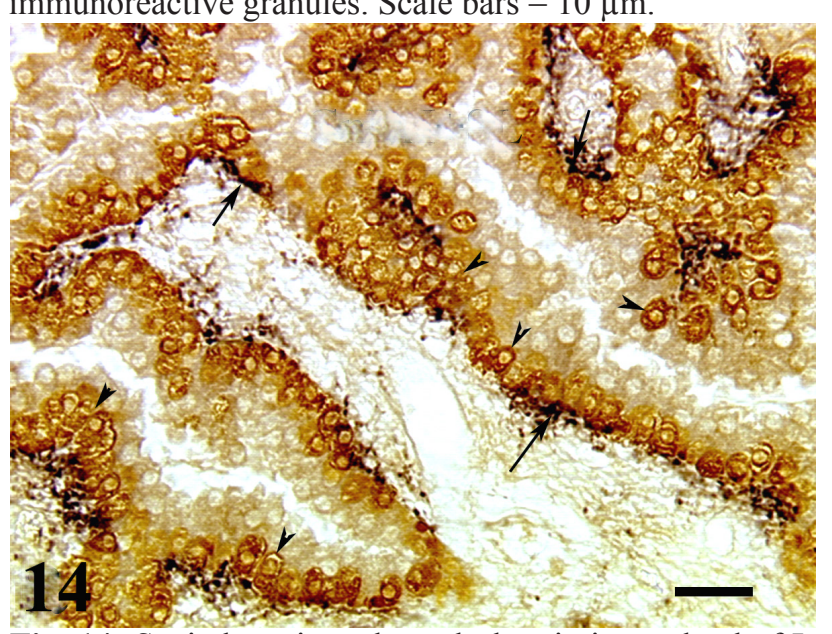

Fig. 14: Sagital sections through the pituitary gland of L. ramada female, showing black mGnRH-IR fibers (arrows) in close contact with brown SL-IR cells (arrowheads) within the pituitary gland of pre-spawning female. Note the strong immunoreactivity of both $\mathrm{mGnRH}-\mathrm{IR}$ fibers and SL-IR cells. Scale bars $=20 \mu \mathrm{m}$. 


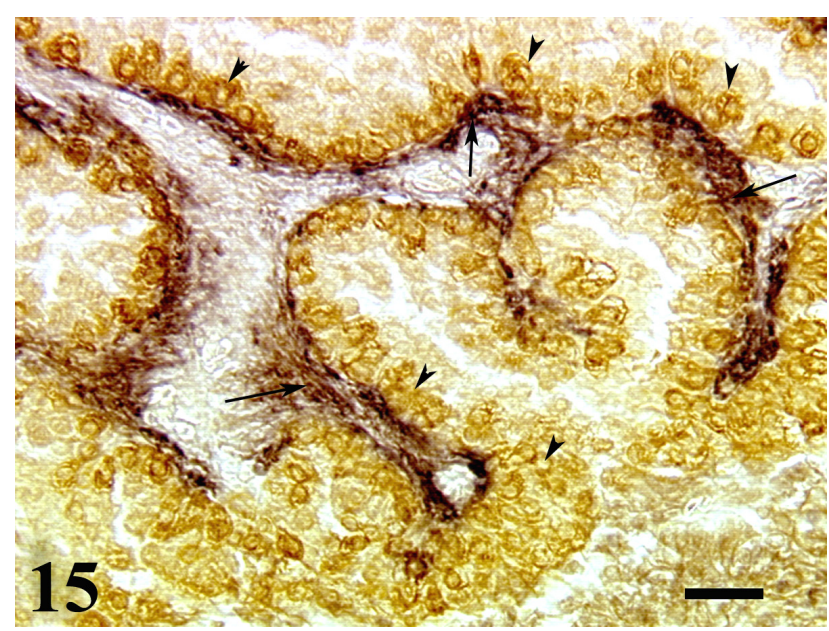

Fig. 15: Sagital sections through the pituitary gland of L. ramada female, showing black mGnRH-IR fibers (arrows) in close contact with brown SL-IR cells (arrowheads) within the pituitary gland of mature injected female. Note the moderate immunoreactivity of both $\mathrm{mGnRH}$-IR fibers and SL-IR cells. In addition, the density of mGnRHIR fibers was higher than in pre-spawning female. Scale bars $=20 \mu \mathrm{m}$.

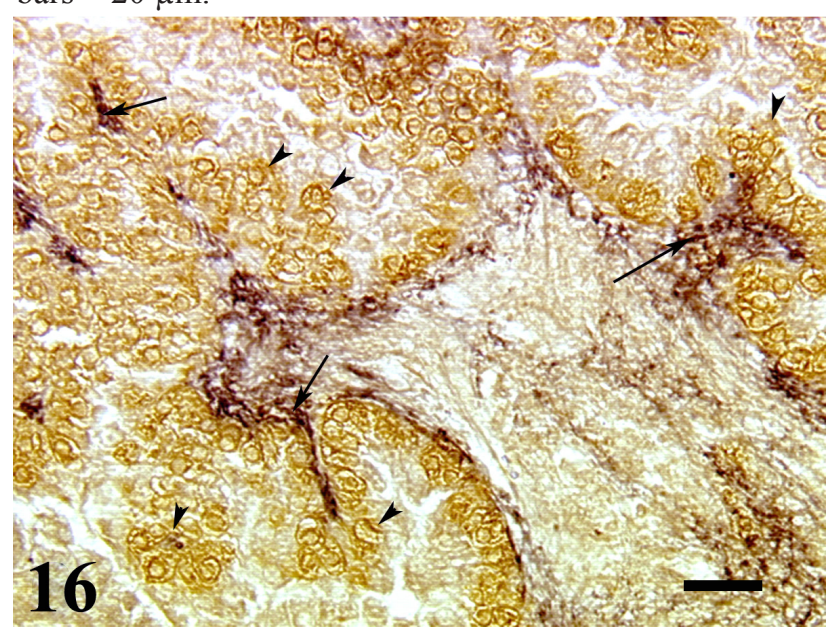

Fig. 16: Sagital sections through the pituitary gland of L. ramada female, showing black mGnRH-IR fibers (arrows) in close contact with brown SL-IR cells (arrowheads) within the pituitary gland of postspawning female. Note the weak immunoreactivity of both mGnRH-IR fibers and SL-IR cells. Scale bars $=20 \mu \mathrm{m}$.

\section{DISCUSSION}

The females of $\mathrm{L}$. ramada did not complete final maturation in the captivity. Therefore, the completion of maturation and spawning of these fish is possible in the captivity by hormonal therapies in combination with environmental factors, particularly water temperature and salinity ${ }^{[3,}{ }^{37]}$. Our results revealed that the use of pregnyl ( $\mathrm{HCG})$ as a priming and resolving injections proved to be effective in inducing ovulation and spawning in L. ramada, at 44 to $52 \mathrm{~h}$ after hormonal injection. This may be due to the direct effect of HCG on the gonads. However, luteinizing hormone-releasing hormone analogue des-
Gly10 (D-Ala6) LHRH-Ethylamide (LHRHa) has been successfully used to induce final maturation and synchronize ovulation of some fish $^{[38-43]}$. The process of oocyte maturation was associated with significant and continuous increases in oocyte diameter. Similar increase in oocyte size during oocyte maturation has been observed for many fishes, and has been attributed primarily to water uptake ${ }^{[4]}$. Oocyte maturation began with lipid droplet coalescence, which occurred concomitantly with GV migration. The GV is always attached to the largest lipid droplet and appears to be pushed to the periphery by the mere enlarging of the coalesced lipid-mass, a characteristic similar to that of Dicentrarchus labrax, M. cephalus and Morone saxatilis $^{[1,45,46]}$. Fusion of yolk globules is common in many fishes, in most species it happens during oocyte maturation, however in some it occurs during vitellogenesis ${ }^{[4]}$. This process is very common in fish, especially in marine species that spawn pelagic eggs $^{[47-50]}$. The late oocyte maturation phase consisted of GVBD and yolk-globule coalescence in which clearing process began and consequently the oocytes appear progressively more translucent. Similar observations were recorded for M. cephalus ${ }^{[1]}$.

It is well established that $\mathrm{GnRH}$, a decapeptide, represents one of the main stimulatory factors involved in the synthesis and releasing of GTHs in fish ${ }^{[7,8,51]}$. In this research, we used specific antibodies for $\mathrm{GnRH}$ and chum salmon SL, immunohistochemistry to investigate the immunoreactivities of these hormones in the brain and pituitary gland of L. ramada during induced spawning. The mGnRH-IR cell bodies were observed in the medulla oblongata within the brain of L. ramada. However, the SL-IR cells were only detected in the PI of the examined individuals. Moreover, our double immunostaining revealed a close association between mGnRH-IR fibers and SL-IR cells in the PI area of pituitary gland. These findings are in agreement with previous study demonstrated $\mathrm{mGnRH}$-IR fibers in close vicinity with SL-IR pituitary cells in the Nile perch $^{[11]}$. There is pharmacological and morphological evidence showing that GnRH could be involved in SL release. GnRH stimulated dopamine inhibited SL release in vitro ${ }^{[13]}$. In addition, injection of $\mathrm{GnRH}$ stimulated the release of SL during the induction of maturation and ovulation in Liza ramada ${ }^{[50]}$. The immunohistochemical results obtained in O. mykiss ${ }^{[16]}$, O. bonariensis ${ }^{[32]}$ and in L. niloticus ${ }^{[11,12]}$ suggest that GnRH-IR fibers ending in contact with SL-IR cells can be the morphological substrate of GnRH action on SL release and this could be a common pattern in teleost fishes.

Interestingly, the present study demonstrated that the activity of the mGnRH-IR neurons in the medulla oblongata and mGnRH-IR fibers as well as SL-IR pituitary cells in the PI increased during spawning of 
L. ramada. Similar immunohistochemical observations were obtained in Oncorhynchus nerka and O. keta ${ }^{[19}$, ${ }^{30]}$, O. niloticus ${ }^{[17]}, \mathrm{M}$. cephalus $^{[18]}$, O. bonariensis ${ }^{[31]}$ and in L. niloticus ${ }^{[12]}$. In addition, seasonal changes in GnRH concentrations were observed during the reproductive cycle of Sebastes rastrelliger ${ }^{[52]}$ and Myxine glutinosa ${ }^{[53]}$. Also, mGnRH-ir fibers and SLIR cells in the PI showed quantitative and qualitative seasonal changes during gonadal maturation and spawning in both sexes of L. niloticus ${ }^{[12]}$.

During the final maturation stage of the ovaries in L. ramada, $m$ GnRH-IR neurons, $m G n R H-I R$ fibers and SL-IR cells exhibited a marked degree of hypertrophy and showed strong immunoreaction. Finally, by the approach of postspawning phase of the ovary, the immunostaining intensities and size of mGnRH-IR neurons, mGnRH-IR fibers and SL-IR cells appeared greatly reduced, most of mGnRH-IR neurons and SLIR cells appeared to empty their secretory contents as indicated by their small size and presence of secretory vacuoles. The active release of SL granules during spawning of L. ramada may indicate the involvement of SL not only in gonadal deveopment but also in energy mobilization related to reproduction, since the biological events, during spawning process, concerned with reproduction require a great deal of energy. Activated SL cells identified immunohistochemically, were seen also in spawning of Oncorhynchus nerka, O. keta and O. tshawytscha ${ }^{[19,30]}$, M. cephalus ${ }^{[18]}$ and in L. niloticus ${ }^{[12]}$. Also, Somatolactin in the pituitary of blue gourami (Trichogaster trichopterus) was higher in females at low vitellogenesis compared to females with oocytes in maturation ${ }^{[22]}$. Moreover, our immunohistochemical results are in agreement with the biochemical studies, which revealed increase of SL levels during the spawning migration of chum salmon Oncorhynchus keta ${ }^{[54]}$. Furthermore, a hypercalcemic effect of SL was indicated in previous studies: SL cells are activated by low environmental $\mathrm{Ca} 2+$ levels and plasma SL levels are elevated in association with the increase in plasma $\mathrm{Ca} 2+$ levels in stressed and exercised fish ${ }^{[24,55,56]}$. Although the activation of SL cells during ovarian maturation development suggests a hypercalcemic effect of SL, it is likely that other hormones, such as prolactin, stanniocalcin and calcitonin, are involved in calcium homeostasis in teleosts $^{[57-59]}$. It is clearly necessary to examine the role of SL in calcium homeostasis in the context of other calcemic hormones.

In summary, the dominance of $\mathrm{mGnRH}$ in the medulla oblongata and the pituitary gland and its immunoreactivity in relation to seasonal changes in reproductive condition establishes the concept that $\mathrm{mGnRH}$ is the functional form of $\mathrm{GnRH}$ with respect to SL release and the regulation of reproductive activity in L. ramada. Also, the gradual stimulation of
SL synthesis and release during spawning of L. ramada suggests that SL may be involved in the control of some biological events concerned with reproduction, such as calcium metabolism and energy mobilization.

\section{CONFLICT OF INTEREST}

The author declares there are no conflicts of interest.

\section{ACKNOWLEDGEMENT}

We are extremely grateful to Professor Shaaban Mousa (Clinic for Anaesthesiology, Charity University of Medicine, Berlin) for critical review of the manuscript.

\section{REFERENCES}

1. Mousa MA. Biological studies on the reproduction of mullet (Mugil cephalus L.) in Egypt. Ph.D. Thesis. Ain Shams University (1994) 278 pp.

2. Mousa SA, Mousa MA. Immunocytochmical studies of the gonadotropic cells in the pituitary gland of female mullet, Mugil cephalus during the annual reproductive cycle in both natural habitat and captivity. J Egypt Ger Soc Zool (1997) 23 (c): 1736.

3. Mousa MA. Induced spawning and embryonic development of Liza ramada reared in freshwater ponds. Animal Reproduction Science (2010) 119: 115-122.

4. Mousa MA, Mousa SA. Involvement of corticotropin releasing factor and adrenocorticotropic hormone in the ovarian maturation, seawater acclimation and induced-spawning of Liza ramada. Gen Comp Endocrinol (2006) 146: 167-179.

5. Szabó T, Medgyasszay C, Horváth L. Ovulation induction in nase (Chondrostoma nasus, Cyprinidae) using pituitary extract or $\mathrm{GnRH}$ analogue combined with domperidone. Aquaculture (2002) 203: 389-395.

6. Peter RE, Trudeau VL, Sloley BD, Peng C, Nahorniak CS. Actions of catecholamines, peptides and sex steroids in regulation of gonadotropin-II in the goldfish. In: Scott, A.P., Sumpter, J.P., Kime, D.E., Rolfe, M.S. (Eds.), Reproductive Physiology of Fish, Fish Symposium 91. University of East Anglia Printing Unit, Sheffield, (1991) 30-34 pp.

7. Levy G, Degani G. The role of brain peptides in the reproduction of blue gourami males (Trichogaster trichopterus). J Exp Zool (2013) 9999A:1-10.

8. Servili A, Herrera-Pérez P, Salmerón JAP, Kah O, Muñoz-cueto JA. Neuroendocrine Regulation of Reproduction in Sea Bass (Dicentrarchus labrax). 
In: F.J.S. Vázquez and J.A. Muñoz-cueto (eds). Biology of European sea bass. CRC Press, Taylor \& Francis Group, Boca Raton, London, Newyork, USA (2014) 116-161 pp.

9. Sower SA. The Reproductive HypothalamicPituitary Axis in Lampreys. In: M. F. Docker (ed.), Lampreys: Biology, Conservation and Control, Springer, Dordrecht, Heidelberg, Newyork, London (2015) 305-373 pp.

10. Muske LE. Evolution of gonadotropin-releasing hormone $(\mathrm{GnRH})$ neuronal systems. Brain Behav Evol (1993) 42: 215-230.

11. Mousa MA, Mousa SA. Immunohistochemical localization of gonadotropin releasing hormones in the brain and pituitary gland of the Nile perch, Lates niloticus (Teleostei, Centropomidae). Gen Comp Endocrinol (2003) 130: 245-255.

12. Khalil NA, El-Gamal AS, Gaber SA, Mousa MA. Immunohistochemical localization of gonadotropinreleasing hormone and somatolactin during sexual maturation and spawning of Lates niloticus. J Biol Sci (2007) 7 (7): 1102-1111.

13. Kakizawa S, Kaneko T, Hirano T. Effects of hypothalamic factors on somatolactin secretion from the organ-cultured pituitary of rainbow trout. Gen Comp Endocrinol (1997) 105: 71-78.

14. Taniyama S, Kitahashi T, Ando H, Kaeriyama M, Zohar Y, Ueda H, Urano A. Effects of gonadotropinreleasing hormone analog on expression of genes encoding the growth hormone/prolactin/somatolactin family and a pituitary-specific transcription factor in the pituitaries of pre-spawning sockeye salmon. Gen Comp Endocrinol (2000) 118: 418-424.

15. Kumar Bhandari R, Taniyama S, Kitahashi T, Ando H, Yamauchi K, Zohar Y, Ueda H, Urano A. Seasonal changes of responses to gonadotropin-releasing hormone analog in expression of growth hormone/ prolactin/somatolactin genes in the pituitary of masu salmon. Gen Comp Endocrinol (2003) 130: 55-63.

16. Parhar SI, Iwata M. Gonadotropin-releasing hormone $(\mathrm{GnRH})$ neurons project to growth hormone and somatolactin cells in the steelhead trout. Histochemistry (1994) 102: 195-203.

17. Mousa MA, Mousa SA. Immunocytochemical study on the localization and distribution of the somatolactin cells in the pituitary gland and the brain of Oreochromis niloticus (Teleostei, Cichlidae). Gen Comp Endocrinol (1999) 113: 197-211.

18. Mousa MA, Mousa SA. Implication of somatolactin in the regulation of sexual maturation and spawning of Mugil cephalus. J Exp Zool (2000) 287: 62-73.
19. Olivereau M, Rand-Weaver M. Immunocytochemical study of the somatolactin cells in the pituitary of pacific salmon, Oncorhynchus nerka, and O.Keta at some stages of the reproductive cycle. Gen Comp Endocrinol (1994a) 93: 28-35.

20. Rand-Weaver M, Pottinger TG, Sumpter JP. Pronounced seasonal rhythms in plasma somatolactin levels in rainbow trout. J Endocrinol (1995) 146:113 -119.

21. Honji RM, Nóbrega RH, Pandolfi M, Shimizo A, Borella MI, Moreira RG. Immunohistochemical study of pituitary cells in wild and captive Salminus hilarii (Characiformes: Characidae) females during the annual reproductive cycle. Springer Plus, (2013) 2-460:1-14.

22. Degani G. Somatolactin Transcription during Oogenesis in Female Blue Gourami (Trichogaster trichopterus). Advances in Biological Chemistry (2015) 5: 279-285.

23. Kaneko T, Hirano T. Role of prolactin and somatolactin in calcium regulation in fish. $\mathrm{J}$ Exp Biol (1993) 184: 31-45.

24. Kakizawa S, Kaneko T, Hirano T. Elevation of plasma somatolactin concentrations during acidosis in rainbow trout (Oncorhynchus mykiss). J Exp Biol (1996) 199: 1043-1051.

25. Lu M, Swanson P, Renfro L. Effect of somatolactin and related hormones on phosphate transport by flounder renal tubule primary cultures. Am J Physiol Regul Integr Comp Physiol (1995) 268: R577-R582.

26. Company R, Calduch-Giner JA, Mingarro M, PérezSánchez J. cDNA cloning and sequence of European sea bass (Dicentrarchus labrax) somatolactin. Comp Biochem Physiol B (2000) 127: 183-192.

27. Zhu Y, Thomas P. Elevations of somatolactin in plasma and pituitaries and increased a-MSH cell activity in red drum exposed to black background and decreased illumination. Gen Comp Endocrinol (1996) 101: 21-31.

28. Zhu Y, Thomas P. Effects of light on plasma somatolactin levels in red drum (Sciaenops ocellatus). Gen Comp Endocrinol (1998) 111: 76-82.

29. Nguyen N, Sugimoto M, Zhu Y. Production and purification of recombinant somatolactin $\beta$ and its effects on melanosome aggregation in zebrafish. Gen Comp Endocrinol (2006) 145: 182-187.

30. Olivereau M, Rand-Weaver M. Immunoreactive cells in the pituitary of young, migrating and spent Chinook salmon (Oncorhynchus tshawytscha). Fish Physiol Biochem (1994b) 13: 141-151. 
31. Vissio PG, Andreone L, Paz DA, Maggese MC, Somoza GM, Strüssmann CA. Relation between the reproductive status and somatolactin cell activity in the pituitary of Pejerrey, Odontesthes bonariensis (Atheriniformes). J Exp Zool (2002) 293: 492-499.

32. Vissio PG, Stefano AV, Somoza GM, Maggese MC, Paz DA. Close association of gonadotropinreleasing hormone fibers and gonadotropin, growth hormone, somatolactin and prolactin expressing cells in pejerrey, Odontesthes bonariensis. Fish Physiol Biochem (1999) 21: 121-127.

33. Mousa MA. The efficacy of clove oil as an anaesthetic during the induction of spawning of thinlipped grey mullet, Liza ramada (Risso). J Egypt Ger Soc Zool (2004) 45 (A): 515-535.

34. Shehadeh ZH, Kuo CM, Milisen K. Validation of an in vivo method for monitoring ovarian development in the grey mullet (Mugil cephalus). J Fish Biol (1973) 5: 489-496.

35. Crim LW, Glebe BD. Reproduction. In: C.B. Schreck \& P.B. Moyle (ed.) Methods for Fish Biology, American Fisheries Society, Bethesda (1990) 529-554 pp.

36. Conn HJ. Biological stains. Baltimore: Williams and Wilkins Company (1953) 1-692 pp.

37. Mousa MA, Khalil NA. Environmental and hormonal control of induced spawning in thinlipped grey mullet, Liza ramada (Risso). Egypt J Histol (2013) 36 (2):449-458.

38. Park IS, Chung EY, Hong KP. Hormonal induction of ovulation in the coho salmon, Oncorhynchus kisutch. J Aquaculture (1997) 10: 485-486.

39. Basaran F, Filizkan B, Boyacioglu H, Ozden O, Ozkizilcik S. Induced Spawning, Fertilization Rate and Hatching Rate of Brill, Scophthalmus rhombus. Journal of Applied Biological Sciences (2008) 2 (1): 17-21.

40. Mylonas CC, Fostier A, Zanuy S. Broodstock management and hormonal manipulations of fish reproduction. Gen Comp Endocrinol (2010) 165: 516-534.

41. Bondarenko V, Podhorec P, Svinger VW, Policar T. Evaluation of Treatments for Induction of Ovulation in Northern Pike (Esox lucius L.). Turkish Journal of Fisheries and Aquatic Sciences (2015) 15: 581-587.

42. El-Hawarry WN, Abd El-Rahman SH, Shourbela RM. Breeding response and larval quality of African catfish (Clarias gariepinus, Burchell 1822) using different hormones/hormonal analogues with dopamine antagonist. Egyptian Journal of Aquatic Research (2016) 42, 231-239.

43. Presello AJ. "Brood Stock Establishment through Hormonal Induction of Gamete Expression and Cryopreservation of Spermatozoa in Bloaters (Coregonus hoyi)". Electronic Theses and Dissertations (2016) Paper 5784.

44. Wallace RA, Selman K. Cellular and dynamic aspects of oocyte growth in teleosts. American Zoologist (1981) 21: 325-343.

45. Alvarino JMR, Carrillo M, Zanuy S, Prat F, Mananos E. Pattern of sea bass oocyte development after ovarian stimulation by LHRHa. J Fish Biol (1992) 41: 965-970.

46. Mylonas CC, Woods LC III, Zohar Y. Cytohistological examination of post-vitellogenesis and final oocyte maturation in captive-reared striped bass. J Fish Biol (1997) 50: 34-49.

47. Wallace RA, Selman K. Major protein changes during vitellogenesis and maturation of Fundulus oocytes. Dev Biol (1985) 110: 492-498

48. Greeley MSJr, Calder DR, Wallace RA. Changes in teleost yolk proteins during oocyte maturation: correlation of yolk proteolysis with oocyte hydration. Comp Biochem Physiol (1986) 84B: 1-9.

49. Matsubara T, Adachi S, Ijiri S, Yamauchi K. Changes of lipovitellin during in vitro oocyte maturation in Japanese flounder Paralichthys olivaceus. Fisheries Science (1995) 61: 478- 481

50. Mousa MA. Hormonal induction of oocyte final maturation and ovulation in thin-lipped grey mullet, Liza ramada (Risso). Bull Nat Inst of Oceanogr Fish ARE (1999) 25: 331-355.

51. Zohar Y, Muñoz-Cueto JA, Elizur A, Kah O. Neuroendocrinology of Reproduction in Teleost Fish. Gen Comp Endocrinol (2010) 165: 438-55.

52. Collins PM, O’Neill DF, Barron BR, Moore RK, Sherwood NM. Gonadotropin-Releasing Hormone Content in the Brain and Pituitary of Male and Female Grass Rockfish (Sebastes rastrelliger) in Relation to Seasonal Changes in Reproductive Status. Biol Reprod (2001) 65: 173-179.

53. Kavanaugh SI, Powell ML, Sower SA. Seasonal changes of gonadotropin-releasing hormone in the Atlantic hagfish Myxine glutinosa. Gen Comp Endocrinol (2005) 140: 136-143. 
54. Kakizawa S, Kaneko T, Ogasawara T, Hirano $\mathrm{T}$. Changes in plasma somatolactin levels during spawning migration of chum salmon (Oncorhynchus keta). Fish Physiol Biochem (1995b) 14: 93-191.

55. Kakizawa S, Kaneko $\mathrm{T}$, Hasegawa $\mathrm{S}$, Hirano $\mathrm{T}$. Activation of somatolactin cells in the pituitary of the rainbow trout Oncorhynchus mykiss by low environmental calcium. Gen Comp Endocrinol (1993) 91: 298-306.

56. Kakizawa S, Kaneko T, Hasegawa S, Hirano $\mathrm{T}$. Effects of feeding, fasting, background adaptation, acute stress and exhaustive exercise on the plasma somatolactin concentrations in rainbow trout. Gen Comp Endocrinol (1995a) 98: 137-146.
57. Hirano T. The corpuscles of Stannius. In "Vertebrate Endocrinology" (P. K. T. Pang and M. P. Schreibman, Eds.). Academic Press, San Diego, CA (1989) Vol. 3, 139-170 pp.

58. Copp DH, Kline LW. Calcitonin. In "Vertebrate Endocrinology" (P. K. T. Pang and M. P. Schreibman, Eds.). Academic Press, San Diego, CA (1989) Vol 3: 79-104 pp.

59. Wendelaar Bonga SE, Pang PKT. Control of calcium regulating hormones in the vertebrates: Parathyroid hormone, calcitonin, prolactin, and stanniocalcin. Int Rev Cytol (1991) 128: 139-213. 
الملخص العربى

دراسة هستوكيميائية مناعية للهرمون المحرر لهرمون الجونادوتروبين وهرمون السوماتولاكثين أثناء التفريخ المحفزّز لأسماك الطوبنار

مصطقى عبد الوهاب' موسى، نهى عبد الحميد خليل'، أمل محمد هاثم'، محمد فتحى قورة'

'معمل تناسل وتفريخ الأسماك ـ المعهد القومى لعلوم البحار والمصايد

بقسم علم الحيوان - كلية العلوم - جامعة الزقازيق

المقدمة: يعتبر الهرمون المحرر لهرمون الجونادونروبين منظم فعال لتطور المناسل و التفريخ فى الأسماك. بالإضافة إلى أنه يعتبر متحكم فى إفراز هرمون السوماتو لاكتين فى الأسماك. بالر غم من ذللك لاتوجد معلومات متاحة توضح العلاقة بين الهرمون المحرر لهرمون الجونادوتروبين وهرمون السوماتو لاكتين أثناء تكاثر أسماك الطوبار. الهدف من الدراسة: وقد صممت هذه الدراسة لفحص التفاعل المناعى لكل من الهرمون المحرر لهرمون الجونادوتروبين وهرمون السوماتو لاكتين أثناء تحفيز النضج النهائى، التبويض و التفريخ فى أسماك الطوبار وذلك من أجل توضيح دور هذه الهرمونات فى النضج الجنسى و التفريخ فى الأسماك المادة والطرق : تم استخدام الطرق الهستولوجية و الهستوكيميائية المناعية لوصف التفاعل المناعى لكل من الهرمون المحرر لهرمون الجونادوتروبين و هرمون السوماتو لاكتين أثناء نضج المبيض و التفريخ لأسماك الطوبار. النتائج: تم إكتشاف الخلايا العصبية المفرزة للهرمون المحرر لهرمون الجونادوتروبين الثديى فى منطقة النخاع المستطيل من المخ. بينما تم تحديد التفاعل المناعى للخلايا المفرزة لهرمون السوماتو لاكتين فى الجزء المتوسط من الغدة النخامية. وقد وجد إتصال وثيق بين النهايات العصبية والخلايا المفرزة لهرمون السوماتو لاكتين. وأظهرت النتائج إزدياد نشاط كل من الهرمون المحرر لهرمون الجونادوتروبين وهرمون السوماتو لاكتين أثناء النضج الجنسى والتفريخ لأسماك الطوبار و الذى تمثل فى لى زيادة أعداد تلك الخلايا وحجمها. وقد إتضح إزدياد نشاط تلكك الخلايا بزيادة حجمهاو وعدها وتفاعلها المناعى فى مرحلة ماقبل الهجرة للإناث. بينما إزداد النشاط الإفرازى للخلايا العصبية المفرزة للهرمون المحرر لهرمون الجونادوتروبين وهرمون السو ماتو لاكتين أثناء النضج النهائى و التفريخ كما اتضح من صغر حجمها وامتلاكها لفجوات إفرازية وتفاعل مناعى ضعيف. الخلاصة: تثتير النتائج الحالية إلى وجود إتصال وثيق بين النهايات العصبية المفرزة للهرمون المحرر لهرمون الجونادوتروبين و هرمون السوماتو لاكتين فى الغدة النخامية وأيضا وجود تغيرات متزامنة لكل من الهرمون المحرر لهرمون الجونادوتروبين و هر مون السو ماتو لاكتين يؤدى إلى الإفتر اض بأن الهرمون المحرر لهرمون الجونادوتروبين ربما يكون مسئو لا عن تتظيم إفراز هرمون السوماتو لاكتين أثناء التكاثر لأسماك الطوبار 